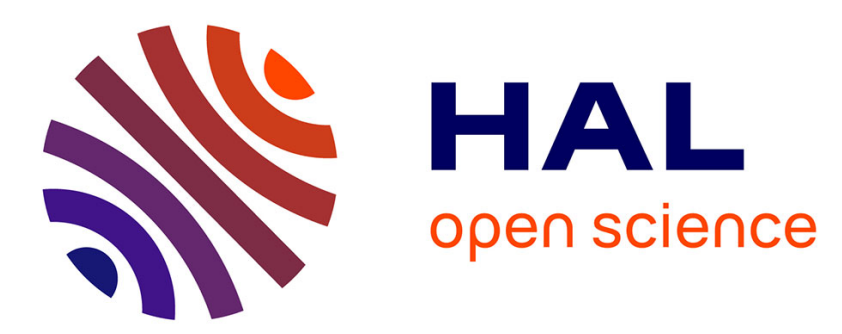

\title{
Investing Human Capital: Angel Cognition and Active Involvement in Business Angel Groups
}

Peter Wirtz, Christophe Bonnet, Laurence Cohen, Christophe Haon

\section{To cite this version:}

Peter Wirtz, Christophe Bonnet, Laurence Cohen, Christophe Haon. Investing Human Capital: Angel Cognition and Active Involvement in Business Angel Groups. Revue de l'Entrepreneuriat, 2020, 19 (1), pp.43-60. 10.3917/entre1.191.0043 . halshs-02374570

\section{HAL Id: halshs-02374570 \\ https://shs.hal.science/halshs-02374570}

Submitted on 21 Nov 2019

HAL is a multi-disciplinary open access archive for the deposit and dissemination of scientific research documents, whether they are published or not. The documents may come from teaching and research institutions in France or abroad, or from public or private research centers.
L'archive ouverte pluridisciplinaire HAL, est destinée au dépôt et à la diffusion de documents scientifiques de niveau recherche, publiés ou non, émanant des établissements d'enseignement et de recherche français ou étrangers, des laboratoires publics ou privés. 


\section{Investing Human Capital: Angel Cognition and Active Involvement in Business Angel Groups}

Peter Wirtz,

Professeur des Universités,

Université de Lyon, iaelyon, Centre Magellan

6, Cours Albert Thomas - BP 8242- 69355 Lyon Cedex 08

peter.wirtz.fcs@gmail.com

Christophe Bonnet,

Professeur

Grenoble Ecole de Management, Univ Grenoble Alpes ComUE 12 Rue Pierre Sémard, 38000 Grenoble

christophe.bonnet@grenoble-em.com

Laurence Cohen

Maître de Conférences

Université de Lyon, iaelyon, Centre Magellan

6, Cours Albert Thomas - BP 8242- 69355 Lyon Cedex 08

laurence.cohen@univ-lyon3.fr

Christophe Haon,

Professeur

Grenoble Ecole de Management, Univ Grenoble Alpes ComUE

IREGE, Université Savoie Mont Blanc

12 Rue Pierre Sémard, 38000 Grenoble

christophe.haon@grenoble-em.com 


\title{
Investing Human Capital: Angel Cognition and Active Involvement in Business Angel Groups
}

\begin{abstract}
The present research sets out to reach a better understanding of the determinants of business angels' active involvement in making business angel groups accomplish diverse functions and building cognitive resources and shared competencies. We develop a framework where angels' decision making style and professional experience are key in explaining their degree and type of involvement with diverse business angel group activities. To test the related propositions, we conduct a questionnaire survey with the members of one of the largest French business angel groups. Our results show that business angels with a control-oriented decision-making style, as well as angels with previous professional experiences as a CEO and in marketing and sales, tend to be more actively involved in key angel group activities, both with regard to investment related activities and angel group management activities. While discussing the results, we propose a tentative model of angel group cognition and outcomes for future extensions of the present research.
\end{abstract}

Keywords: business angel groups; business angel group activities; decision making style; human capital.

\section{Résumé}

La présente recherche vise à mieux comprendre l'implication active des business angels au sein des groupes de business angels, ainsi que la construction cognitive des ressources et le partage des compétences. Nous développons un cadre conceptuel où le style de prise de décision des business angels et leur expérience professionnelle sont des clés pour expliquer leur degré et leur type d'implication parmi les diverses activités du groupe de business angels. Afin de tester les propositions, nous avons mené une enquête sous forme d'un questionnaire auprès d'un des plus grands groupes de business angels français. Nos résultats montrent que les business angels ayant un style de prise de décision « orienté-contrôle » ainsi que ceux ayant une expérience professionnelle en tant que directeur et en marketing et ventes sont plus impliqués dans les activités du groupe de business angels tant au niveau des activités d'investissement que des activités de management du groupe de business angels lui-même. Au titre des futures recherches qui pourraient prolonger ce travail, nous proposons un modèle de groupe de business angels, en termes de cognition et de performance.

Mots clés : groupe de business angels ; activités d'un groupe de business angels ; style de prise de décision ; capital humain. 
Business angels (BAs), that is to say "high net worth individuals" (Wetzel, 1983) investing their own money in unquoted enterprises, have been shown to play an important role in closing the equity gap for early stage ventures. Most of the initial research on the population of angels was dedicated to the study of their individual demographic and cognitive characteristics and the latter's impact on investment behaviour and outcomes. Certain cognitive characteristics in terms of decision-making style (Wiltbank, Read, Dew and Sarasvathy, 2009) and knowledge gained from former experience (Capizzi, 2015) have been highlighted as important drivers of investment decision making and performance. In fact, research on individual BAs indicates that depending on their knowledge and experience, angels engage in value added activities for the ventures they invest in, such as mentoring the entrepreneur, acting as a sounding board for strategy formulation, etc. (Bonnet and Wirtz, 2012).

The angel market has however undergone significant transformation over the past two decades. Individual BAs have had a tendency to group together into informal networks or more structured angel groups which help them lever individual knowledge and know-how of certain group members to the benefit of all, hence achieving increased standardization and professionalization of investment practices. The spread of business angel networks and groups over the past 20 years is a significant evolution of the market for entrepreneurial finance (Mason Botelho and Harrison, 2016; Wallmeroth, Groh, Wirtz, 2018), increasing its effectiveness. Whereas angel networks provide essentially introduction services with entrepreneurs, angel groups enable their members to invest collectively. They therefore perform various value added activities along the investment cycle, from deal sourcing to exit, all of which could hardly be performed all at once by individual angels (Bonini, Capizzi, Valletta and Zocchi, 2018). However, although they deeply transform the business angel market through an increase in funding supply and a professionalization and better efficacy of BAs activity, angel groups have raised limited attention from scholars so far (Carpentier and Suret, 2015; Mason, Botelho and Harrison, 2016).

This research is focussed on a key determinant of business angel groups' sound functioning and efficacy: the involvement of its members in group activities. Indeed, because activities such as selecting investment opportunities, performing due diligence, negotiating with entrepreneurs, monitoring ventures and exits require time, experience and investment skills, a key challenge for angel groups is to attract qualified and active members and mobilize their long term involvement. Even when they employ non-member permanent staff, the latter is mostly dedicated to administrative, networking and deal screening tasks (Paul and Whittam, 2010). Therefore, the functioning and success of an angel group essentially depends on volunteer members' involvement in investment related activities as well as in group management activities (group management and strategy, links with the entrepreneurial eco-system, new members hiring and training...). Previous research has shown that, should they be unable to secure the involvement by qualified members, angel groups may decline and disappear ( $\mathrm{Zu}$ Knyphausen-Aufsess and Westphal, 2008). A potential risk lies in the fact that angel groups partly attract passive members who simply seek to invest their financial capital (Sohl, 2007) and do not participate in investment or group management activities. Although securing members' involvement is a key issue that conditions angel groups' efficacy and survival, it seems that the factors which contribute to such involvement have not yet been investigated by entrepreneurial finance scholars. This research is a first exploratory attempt to fill this 
gap by studying the link between individual cognitive characteristics of angel group members and the degree and nature of their involvement in group activities.

The answer to this question has practical implications, in that better knowledge of the relevant member characteristics to get involved in various activities may help co-opt the right people for the group's management and governance bodies to shape and achieve its specific organizational goals, ultimately leading to overall member-satisfaction and perceived legitimacy. It also has implications for possible extensions of academic research on entrepreneurial finance. For instance, in the past, such research has highlighted the influence of individual BAs' knowledge and decision-making style on their investment behaviour and the performance of the ventures they engage in. Consequently, one may wonder if the same characteristics are also significant drivers of individual BAs' investment of their human capital in angel group activities and, ultimately, the value the group adds for individual members and the investee firms.

To study the assumption that BA decision making style and cognitive characteristics not only influence their decision to invest money in individual ventures but also to invest their human capital in various angel group activities, we conducted a questionnaire survey with a major French regional BA group. The questionnaire was designed to appreciate the degree of overall involvement in group activities, measured by the amount of time invested, as well as the engagement in different types of group activities, as they are typically identified in the literature.

The results show that one of the main drivers of strong group involvement is a control oriented decision making style. In terms of cognitive characteristics, former experience as a CEO as well as functional experience in the fields of marketing and, to a lesser extent, finance and law turn out to be significant determinants of involvement in various BA group activities. We do not find a significant association between an experience as entrepreneur and the involvement in the studied BA group activities.

Our main contribution is to show that individual BAs' decision making style and professional experience are significant drivers of their involvement in BA group activities which serve the whole group collectively. While discussing these results and in an attempt to sketch out possible future extensions of the present research, we build on the literature of entrepreneurial team cognition (Mol, Khapova and Elfring, 2015), to propose a tentative model of business angel group cognition and related possible outcomes. This holds the promise to ultimately extend our knowledge on the inner functioning of business angel groups, who are major actors in the contemporary market for entrepreneurial finance.

The remainder of this article is organized as follows. The first section contains a succinct review of the literature related to angel groups, with a particular focus on the activities typically accomplished by such groups. In a next step, we present a simple model of BA involvement in group activities and develop the related propositions. The following section explicates the methodological aspects of the survey and data analysis. We then present and discuss the results before we finally conclude.

\section{Business angel groups}

In the present section, we briefly describe the major characteristics of angel groups, their impact on the market for entrepreneurial finance (1.1) and the activities typically performed by their members (1.2). 


\subsection{Emergence of angel groups and impact on the entrepreneurial finance market}

Most business angels in the 1980's operated anonymously and individually or in small informal syndicates. The matching of supply and demand of equity capital was therefore highly inefficient. A major transformation was the emergence of business angels networks (BANs) offering introduction services with entrepreneurs, which first appeared in the U.S. in the 1980's and spread to Europe in the 1990's and 2000's. BANs make angel investors visible to entrepreneurs through events, newsletters and the internet (San Jose, Roure and Aernoudt, 2005; EBAN, 2014). They usually perform a first selection of projects before introducing them to their members. Some BANs also develop angel training programs (San Jose, Roure and Aernoudt, 2005). It is generally recognized that BANs have considerably contributed to raise awareness on angel financing and to increase angel investment activity (San Jose, Roure and Aernoudt, 2005, Collewaerdt, Manigart and Arnoudt, 2010; Mason and Harrison, 2002), which has alleviated financing problems for young entrepreneurial companies (Collewaerdt, Manigart and Arnoudt, 2010). However, some BANs fail to provide enough good quality deals to their members and do not succeed in attracting enough angel investors (Mason and Harrison, 2002). Due to the difficulty in establishing a commercially viable activity, many BANs depend on government funding (Mason, Botelho and Harrison, 2016).

A more recent transformation of the business angel market is the spread of more structured angel groups (or syndicates) where business angels organize themselves to invest collectively. This trend appeared in the U.S. in the 1990's and business angel groups are now found all around the world (OECD, 2011). In addition to introduction services, angel groups perform active deal sourcing and selection, evaluation, negotiation and the monitoring of portfolio companies until the exit. Some groups also establish "sidecar funds" which raise capital within and/or outside the group and invest alongside individual angels, thus increasing the capital pool and facilitating portfolio diversification for members.

As Mason, Botelho and Harrison (2016) have shown, angel groups transform the market for entrepreneurial finance in several ways:

- Investments are screened, evaluated and negotiated collectively rather than individually, which enables economies of scale and the development of routines and shared experience. Angel groups can also rely on a rich pool of shared competencies to perform their various activities. Moreover, they facilitate learning, with novice angels beneficiating from the knowledge of more experienced members.

- They increase the supply side of the market by attracting individual investors who, due to the lack of time or investment skills, would rather invest in other assets than in the equity of young ventures.

- Angel groups contribute to fill the equity gap as they invest in small, seed or early stage, financing rounds that are largely deserted by professional venture capitalists. By securing larger amounts of money than most individual angels, they also have greater possibilities to invest in several successive rounds, which reduces the necessity for entrepreneurs to look for new investors each time they raise funds. 
- Due to the range of business expertise that angel groups gather amongst their members, they are in a better position than most individual angels to add value to investee companies by providing mentoring and strategic advice to entrepreneurs. Investee companies beneficiate from this "accreditation" role by securing greater chances to attract capital from professional VCs and from government funded schemes.

\subsection{Activities performed by angel groups}

Angel group activities can roughly be divided into two broad categories: investment related activities, that is to say activities directly related to the investment processes from deal sourcing to exit, and group management activities, which concern the functioning and governance of the angel group itself. As we have seen, angel groups face a situation of scarce resources in terms of full-time staff, and most activities are typically achieved by volunteer angel group members (AGMs). activities.

Based on the literature, we propose the following classification of angel group

Investment activities include:

- Deal sourcing

Members contribute to deal sourcing by referring investment opportunities that they have identified and by contributing to the collective actions developed by the group in order to increase deal flow, such as networking towards the entrepreneurial community and intermediaries (San Jose, Roure and Aernoudt, 2005).

- Deal screening

In most angel groups, a pre-screening is made by a gatekeeper in order to eliminate proposals which do not meet the group investment criteria. Gatekeepers are most often non-member staff whose role is to contribute to networking, deal sourcing and prescreening, and to the coordination of the angel group ((Paul and Whittam, 2010). The second step screening, which aims at selecting the proposals which will enter into a detailed evaluation, generally involves a group of volunteer members with diverse expertise (Carpentier and Suret, 2015; Shane, 2005; Paul and Whittam, 2010).

- Evaluation and negotiation

At this stage, which typically lasts several months, a detailed analysis of the project is performed by a small group of members, often led by a lead AGM who has specific expertise in the field. External validation and information are searched for. Several meetings with the entrepreneurs are organized in order to gain better knowledge of the project and the team, validate the economic viability of the project and detect potential agency problems (Carpentier and Suret, 2015). Then the negotiation of the price and of the contractual agreements takes place. Evaluation and negotiation are time consuming activities which require industrial and financial expertise, and anecdotal evidence indicates that many angel groups meet difficulties in finding volunteer AGMs to perform them.

- Post-investment monitoring

After the investment, one or several AGMs with relevant expertise are nominated to supervise the portfolio company and help it grow and achieve the milestones required for future funding rounds and, possibly, a successful exit. This entails formal board participation and/or informal contacts with the entrepreneurs. The added value by business angels to investee companies through mentoring, advice and assistance in 
gathering resources is largely put in evidence in the literature (Croce, Guerini and Ughetto, 2018; Kerr, Lerner and Schoar, 2014; Madill, Haines and Riding, 2005; Riding, 2008).

Group management activities:

Whereas permanent staff (gatekeepers) are generally in charge of coordinating the day to day functioning (Paul and Wittham, 2010), anecdotal evidence suggests that most angel groups are governed by a formal or informal board (board of directors, management committee...) composed of AGMs. The board defines the strategy, monitors the group and seeks to secure financial and non-financial resources. The latter activities include actions such as networking with other organizations (angel groups, VC firms, entrepreneur associations, banks, professional service firms, incubators and accelerators) and lobbying on legal and tax issues.

Other group management activities include the involvement in training programs directed at novice angels (San Jose, Roure and Aernoudt, 2005) and in investment readiness programs for entrepreneurs (Zu Knyphausen-Aufsess and Westphal, 2008). AGMs may also participate in the investment committees of sidecar funds raised at the initiative of their angel group.

\section{Model and propositions}

Angel group activities require time, expertise, and mostly rely on the involvement of their members. The active involvement of individual members in these activities can be considered as an investment of their individual human capital into the group. Angels' investment behaviour has been shown to be significantly influenced by their decisionmaking style. Wiltbank, Read, Dew and Sarasvathy, (2009) distinguish two types of cognitive profile for BAs in terms of decision-making: predictive and control-oriented. Predictive BAs base their investment decision on the possibility to predict future outcomes and rationally compare expected outcomes to the investment effort, whereas the driver of engagement for control-oriented angels is their feeling that they can actively influence events as they unfold, even when future outcomes are difficult or impossible to predict.

Accordingly, we may suppose that predictive angels who score low on control orientation are passive investors who invest money into the ventures the network presents after the necessary due diligence and evaluation activities have been accomplished. Accordingly, a predictive decision-making style should not be considered to be a significant driver of BA involvement. Control-oriented BAs, on the other hand, can be supposed to invest their human capital, when they have the feeling they can actively contribute to shape the environment they live in, without seeking to systematically optimize expected utility. Collective angel group outcomes and performance are especially hard to define and, hence, even harder to predict. Consequently active involvement in angel-group activities can be supposed to be attractive to strongly controloriented angels only, for they value the feeling of being in control more than the expected economic outcomes.

Hence proposition 1: BAs with a strongly control-oriented decision-making style become intensely involved in angel group activities. 
Strong involvement may be measured in different ways. Time invested is one indicator of overall involvement. The number of different activities in which a BA is involved would be another one.

Figure 1 - A model of BA involvement in angel-group activities

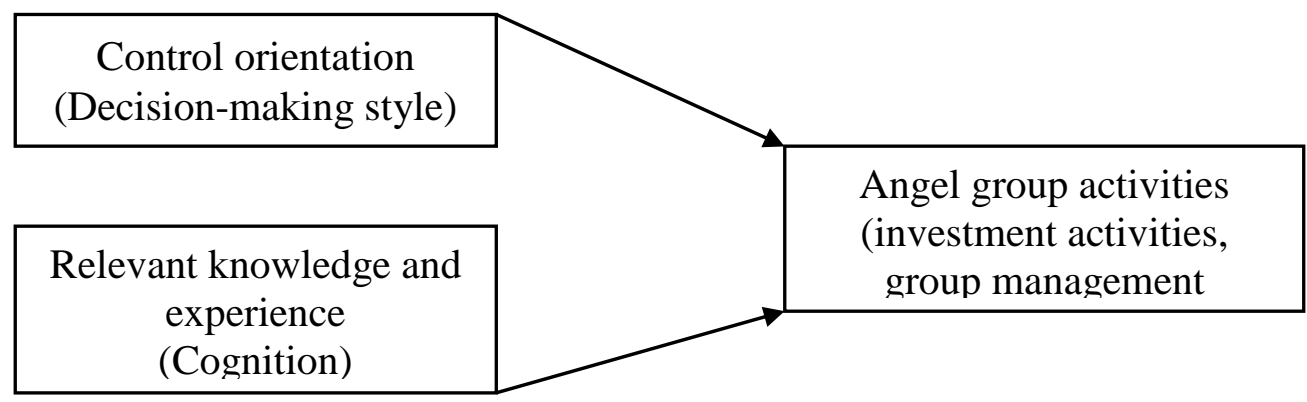

To decide to invest human capital in group activities, angels must also possess the requisite cognitive resources to do so. Different angel group activities potentially require different cognitive resources to be accomplished effectively. Generating deal-flow, for example, depends on an individual's knowledge of the market eco-system and the extent of his or her professional networks. The latter can be supposed to be positively related to certain types of professional experience. The knowledge, know-how and networks acquired through the exercise of specific strategic functions (as a CEO for instance) should be particularly conducive to active involvement in deal evaluation and monitoring, as well as in angel group's strategic activities through board participation. Experience in marketing related functions may also imply good knowledge of the market, which may be a valuable resource to support deal screening and evaluation etc.

Proposition 2: Cognitive resources in the form of relevant professional experience are positively related to BA involvement in various angel-group activities.

\section{Method and results}

The present section provides a description of the studied angel group (3.1), the data collection process and the characteristics of our sample (3.2). This description of the data sampling process is followed by a presentation of the variables we measured (3.3), the data analysis we conducted and, finally, the results we obtained (3.4).

\subsection{The studied angel group}

Previous research suggests that the business angel population is not evenly distributed from a geographic viewpoint. It tends to be concentrated in areas with strong entrepreneurial activity and high income and wealth (Harrison, Mason and Robson, 2010). Savoie-Mont-Blanc Angels (SAMBA) is located in the Auvergne-Rhône-Alpes region in the south-east of France. The region is known for its economic dynamism and intense entrepreneurial activity and hosts some of the larger and more dynamic angel groups in France.

SAMBA was created in 2007 by a group of local entrepreneurs and counts approximately 200 members. Since inception, 65 companies were financed, all located in the Auvergne-Rhône-Alpes region for a total of 9.8 million euros invested. Investee 
companies are mainly young innovative ventures active in high technology, services and industry. This angel group can be qualified as "mature" given its age and the relative stability in the number of members and in the investment activity in the recent years. SAMBA provides a full range of services, i.e. deal sourcing, screening, evaluation and negotiation, post investment monitoring, member training, as well as the management of 8 sidecar funds which have been raised since inception, exclusively from members. AGMs have the option to invest in the companies presented by the group either directly (in this case ad-hoc syndicates are formed) or through the sidecar funds in which they participate.

A staff of 3 part-time employees, led by a gatekeeper, is in charge of administration, coordination, and deal pre-screening. The level of involvement by members in the network activities varies greatly, and most of investment related activities are performed by a core group of 25 to 30 very active members. SAMBA's board of directors counts 15 members including a president (presently one of the network founders).

The investment process of SAMBA takes place according to the following stages. After pre-screening by the gatekeeper, entrepreneurs pitch in front of a screening committee (groupe d'études projets) composed of 5 to 10 AGMs plus the gatekeeper. Selected projects then enter the evaluation and negotiation phase, which is performed by a group of 2 to 3 AGMs (instructeurs) nominated on the basis of expertise and availability. At the end of this phase, which usually lasts between 3 and 6 months, entrepreneurs pitch during the general meeting (réunion plénière) of the angel group. Individual angels and sidecar funds may then decide to invest, sometimes provided final due diligence and negotiation. Each sidecar fund has a dedicated investment committee formed of 10 to 15 volunteer members which discusses the proposed investments and submits them to the vote of the fund investors. After the investment, the network delegates a member (référent) in charge of post-investment monitoring. Référents are volunteers who are chosen on the basis of the added value they can bring to the investee company. They generally join the board or the strategic committee of the company.

\subsection{Data collection and sample}

Given the relatively informal nature of BA activity (when compared to professional VCs), questionnaire surveys are often employed to investigate angel characteristics as well as investment activity, processes and outcomes (Capizzi, 2015; Mason and Harrison, 2002; Wiltbank, Read, Dew and Sarasvathy, 2009). As SAMBA does not formally report the variables we needed to measure to test our model, we developed a specific survey instrument. The survey instrument includes 35 questions and covers four types of data: the individual characteristics of business angels (age, gender...), their satisfaction with network services, their involvement in specific activities, and their decision making style and human capital features (dimensions of prediction and control, as well as functional experience and experience as CEO and entrepreneur). The initial survey instrument was developed by the authors, discussed with the gatekeeper of the angel group and pretested with four AGMs.

The survey was conducted online with Qualtrics survey software. The questionnaire was posted on February 9, 2015 on the internet and an invitation to participate in the study was emailed to the members of SAMBA. A reminder was sent six weeks later. At the closure of the online survey, the total number of respondents was 85 . Forty-three responses were incomplete, taking the initial exploitable sample to 42 
Business Angels. The total population of SAMBA members is estimated to be 197 which results in a response rate of approximately $21 \%$. This is consistent with prior studies investigating business angels and groups in the US and the UK.

In order to increase the response rate, we developed a shorter version of the survey including 26 questions ${ }^{1}$, which was posted on October 28, 2015. At the closure of the online survey, 25 additional new responses were complete, taking the exploitable sample to 67 business angels, which results in a final response rate of approximately $34 \%$.

Our respondents' characteristics are close to those reported in earlier studies in France (Bonnet, Haon and Wirtz, 2013). They are mostly men (91.9\%), aged 63 on average. $75.8 \%$ of them hold a degree in higher education (master level or higher). $59.7 \%$ of them are professionally active, and 69.4\% are subject to the French wealth tax (Impôt de solidarité sur la fortune, paid if net assets exceed $€ 1.3$ million).

$80.6 \%$ of respondents have made at least one investment. Investing angels have made on average 6 investments, of which 4.7 were sourced through SAMBA (or, in case of multi-affiliation, through another angel group) and 1.3 from other sources. In terms of cumulative investment per angel (total since he/she started to invest), two thirds of the respondents have invested between $€ 25,000$ and 100,000 . The distribution of cumulative investment is the following: $11.8 \%$ of respondents invested less than $€ 25,000 ; 37.3 \%$ between $€ 25,000$ and 50,$000 ; 29.4 \%$ between $€ 50,000$ and 100,$000 ; 13.7 \%$ between $€ 100,000$ and 500,000 and $7.8 \%$ above $€ 500,000$.

Most of the respondents $(74.6 \%)$ are satisfied or very satisfied with the services provided by the network (mean score of satisfaction 4.06 on a five-point scale) and $80.6 \%$ consider that the group has made progress in terms of professionalization over the last 10 years.

\subsection{Variables and measures}

- Control orientation

Our first independent variable is the level of respondents' control orientation. We developed a 2-item measure based on the earlier literature (Wiltbank, Read, Dew and Sarasvathy, 2009; Bonnet, Haon and Wirtz, 2013) and selected to fully capture the concept. According to Bonnet, Haon and Wirtz (2013), the scale is formative. It should be noted that this measurement tool, although inspired by effectuation theory, is different from similar scales used to measure concepts of causation and effectuation, such as Chandler, DeTienne, McKelvie and Mumford (2011). The latter were developed to characterize the behavior of entrepreneurs, whereas our measures are tailored to capture the more restrictive and specific context of business-angel investment-decision-making and related activities. We used a five-point Likert scale and respondents rated their agreement or disagreement with each item from 1 (strongly disagree) to 5 (strongly agree). The following items are formative measures of control orientation:

Item 1. When assessing the venture's strategy, you think about the way you can contribute to it;

Item 2. You base your decision to invest in the project on the value added that you are able to deliver through your accompaniment of the company.

\footnotetext{
${ }^{1}$ The 9 questions which were removed in the second version did not relate to the present research project. Consequently, as regards this research, all respondents answered the same questions.
} 
Responses to these two questions were averaged to calculate respondents' control orientation scores. Descriptive statistics of measures are presented in Table 1.

Table 1- Descriptive statistics for control orientation

\begin{tabular}{|l|l|l|l|l|l|}
\hline & N & Min & Max & Mean & s.d. \\
\hline Item 1 & 56 & 1 & 5 & 3.84 & .930 \\
\hline Item 2 & 53 & 1 & 5 & 3.25 & 1.125 \\
\hline Mean score & 52 & 1 & 5 & 3.54 & .959 \\
\hline
\end{tabular}

- Relevant knowledge and experience

Professional experience, a basis for the acquisition of specific human capital, was measured by asking Business Angels to report the number of years spent in various functions at the date of the survey. Descriptive statistics of experience measures are presented in Table 2.

Table 2 - Descriptive statistics for experience measures

\begin{tabular}{|l|c|c|c|c|c|}
\hline & N & Min & Max & Mean & s.d. \\
\hline CEO & 61 & 0 & 40 & 12.92 & 12.328 \\
\hline Strategy & 62 & 0 & 30 & 2.35 & 5.686 \\
\hline Marketing & 62 & 0 & 30 & 3.71 & 8.117 \\
\hline Finance & 62 & 0 & 40 & 7.29 & 11.434 \\
\hline Legal & 62 & 0 & 40 & 2.37 & 6.790 \\
\hline Entrepreneur & 61 & 0 & 40 & 7.23 & 11.948 \\
\hline
\end{tabular}

- Dependent variables

Our aim is to study the effects of control orientation and experience on a number of dependent variables pertaining to the angels' involvement in various angel group activities. First, we asked respondents to indicate which activities they contribute to. For each activity, the measure was dichotomous (i.e. yes/no). Table 3 shows the distribution of their answers.

Table 3 - Distribution of respondents' involvement in angel group activities

\begin{tabular}{|l|c|c|c|}
\hline \multicolumn{1}{|c|}{ Activity } & N & No (\%) & Yes (\%) \\
\hline Deal sourcing & 63 & 76.2 & 23.8 \\
\hline Deal screening & 63 & 57.1 & 42.9 \\
\hline Evaluation and negotiation & 63 & 57.1 & 42.9 \\
\hline Post-investment monitoring & 63 & 60.3 & 39.7 \\
\hline Angel group general meeting attendance & 63 & 6.3 & 93.7 \\
\hline Animation of training seminars & 63 & 93.7 & 6.3 \\
\hline Angel group board participation & 63 & 74.6 & 25.4 \\
\hline Fund investment committee & 63 & 73.0 & 27.0 \\
\hline
\end{tabular}

In addition, we asked respondents how much time they allocate to these activities in a year. The measure is ordinal, and results are described in Table 4. 
Table 4 - Distribution of time allocated to angel group activities (in days per year)

\begin{tabular}{|l|l|l|l|l|l|}
\hline $\mathbf{N}$ & $<\mathbf{1}$ & {$[\mathbf{1}, \mathbf{2}[$} & $\mathbf{2}, \mathbf{6}[$ & {$[\mathbf{6 , 1 2}[$} & $\geq \mathbf{1 2}$ \\
\hline 63 & $7.9 \%$ & $22.2 \%$ & $19.0 \%$ & $33.3 \%$ & $17.5 \%$ \\
\hline
\end{tabular}

- Check for potential bias due to non-response and change of survey instrument

As explained in the previous section, our data was collected in two waves and the second wave relied on a shorter version of the questionnaire. Since the respondents who took the second-wave questionnaire had been invited to take the first one, we consider them as late respondents. We performed a comparison of our measures across data collection waves in order to identify (1) a potential difference between early and late respondents, which would be a signal of a potential non-response bias, and (2) a potential bias introduced by the difference in the measurement instruments (questionnaires).

The mean differences were tested with t-tests for the control orientation and experience measures. No significant differences were found between the two data collection waves (Min. p-value $=.127$ ). As for the categorical measures of participation in and of time allocated to angel group activities, we performed a series of Chi-square tests that shows no significant differences between the two waves (Min. p-value $=.194$ ). We thus conclude that it is reasonable to believe that the presence of a bias due to nonresponse or to the change in the questionnaire should not be suspected.

- Dichotomization of variables

Due to the nature of our measures, the effects of the independent variables would ideally be estimated using logistic regression (for angel group activities) and ordinal logistic regression (for allocated time). However, due to the small size of our sample, these techniques could not be considered because we have less than 10 cases per predictor variable. Consequently, we decided to dichotomize our independent variables and our measure of time allocated to angel group activities. Despite the information loss implied by this decision, we proceeded this way because increasing the sample size was not possible. We recoded control orientation as low for scores from 1 to 3 , and as high otherwise. As for the measures of experience in various functions, we recoded them into 2 categories: 0 if no experience or 1 if at least one year of experience was reported. Finally, we split the measure of time allocated to angel group activities based on whether it is less or more than 6 days per year. The distributions of the dichotomized measures are shown in Table 5.

Table 5 - Distribution of dichotomized variables (in percentage)

\begin{tabular}{|l|l|l|l|}
\hline Measure & $\mathbf{N}$ & Low & High \\
\hline Control orientation & 52 & 38.5 & 51.5 \\
\hline CEO & & No & Yes \\
\hline Strategy & 61 & 27.9 & 72.1 \\
\hline Marketing & 62 & 75.8 & 24.2 \\
\hline Finance & 62 & 72.6 & 27.4 \\
\hline Legal & 62 & 53.2 & 46.8 \\
\hline Entrepreneur & 62 & 80.6 & 19.4 \\
\hline & 61 & 59.0 & 41.0 \\
\hline Time & & $<\mathbf{6}$ days & $\geq \mathbf{6}$ days \\
\hline & 63 & 49.2 & 50.8 \\
\hline
\end{tabular}




\subsection{Data analysis and results}

In order to test our propositions, we cross-tabulated the level of control orientation and the respondents' experience, on the one hand, with the involvement in angel group activities and with the time allocated to these activities, on the other hand. For each pair of variables, we performed a Chi-square test of independence and we calculated Cramér's $\mathrm{V}$ to measure its association with control orientation. When a relation was found (marginally) significant at the .10 level, we inferred its directionality based on the differences between observed and expected frequencies. Results for significant relations are reported in Table 6.

Table 6 - Results of association tests

\begin{tabular}{|c|c|c|c|c|c|c|}
\hline $\begin{array}{l}\text { Independent } \\
\text { variable }\end{array}$ & $\begin{array}{l}\text { Dependent } \\
\text { variable }\end{array}$ & $\mathrm{N}$ & $\begin{array}{l}\text { Chi- } \\
\text { square }\end{array}$ & $\begin{array}{c}p- \\
\text { value }\end{array}$ & $\begin{array}{l}\text { Cramer's } \\
\text { V }\end{array}$ & Directionality \\
\hline \multicolumn{7}{|c|}{ Control orientation } \\
\hline & Deal sourcing & 52 & 3.900 & .048 & .274 & + \\
\hline & Deal screening & 52 & 4.254 & .039 & .286 & + \\
\hline & $\begin{array}{l}\text { Evaluation and } \\
\text { negotiation }\end{array}$ & 52 & 2.925 & .087 & .237 & + \\
\hline & $\begin{array}{l}\text { Angel group } \\
\text { board } \\
\text { participation }\end{array}$ & 52 & 3.036 & .081 & .242 & + \\
\hline & Time & 52 & 3.276 & .070 & .251 & + \\
\hline \multicolumn{7}{|l|}{ CEO } \\
\hline & Deal screening & 61 & 6.767 & .009 & .333 & + \\
\hline & $\begin{array}{l}\text { Evaluation and } \\
\text { negotiation }\end{array}$ & 61 & 10.089 & .001 & .407 & + \\
\hline & $\begin{array}{l}\text { Post-investment } \\
\text { monitoring }\end{array}$ & 61 & 2.969 & .085 & .221 & + \\
\hline \multicolumn{7}{|l|}{ Marketing } \\
\hline & Deal screening & 62 & 6.966 & .008 & .335 & + \\
\hline & $\begin{array}{l}\text { Evaluation and } \\
\text { negotiation }\end{array}$ & 62 & 4.265 & .039 & .262 & + \\
\hline & $\begin{array}{l}\text { Fund } \\
\text { investment } \\
\text { committee }\end{array}$ & 62 & $3.282 *$ & .070 & .271 & + \\
\hline & Time & 62 & 3.377 & .066 & .233 & + \\
\hline \multicolumn{7}{|l|}{ Finance } \\
\hline & $\begin{array}{l}\text { Fund } \\
\text { investment } \\
\text { committee }\end{array}$ & 62 & 5.335 & .021 & .293 & + \\
\hline \multicolumn{7}{|l|}{ Legal } \\
\hline & Deal sourcing & 62 & $3.799 *$ & .051 & .295 & + \\
\hline
\end{tabular}

* Yates' correction applied due to expected frequency lower than 5 in one cell.

All significant associations have the expected directionality. For example, there are more low control respondents than expected who do not participate in deal sourcing, and more respondents with a high control orientation than expected who do participate in deal sourcing. We thus conclude that the higher the level of control orientation, the greater 
the likelihood to participate in deal sourcing, hence the ' + ' sign in the last column of Table 6.

Our results indicate that, as we anticipated, the studied angel group members' control orientation is positively associated with a stronger time involvement in angel group activities. It is also specifically associated with three investment related activities (deal sourcing, deal screening and deal evaluation) as well as with the participation to the angel group's board of directors. Control orientation thus seems to be a significant determinant of an involvement in activities which are key to the efficacy and success of the studied business angel group.

Some specific human capital features, measured by professional experience, are also positively associated with the involvement in angel group activities. An experience as CEO is associated with three investment related activities. CEOs, given their skills and experience in hiring executives, taking strategic decisions (such as launching new products and entering new markets) and monitoring teams and projects should be indeed particularly qualified to screen, evaluate and monitor investment opportunities, which may explain the involvement which is shown by our results. Marketing experience is associated with deal screening, deal evaluation and participation in fund investment committees. The reason might be that an experience in marketing and sales enables BAs to better evaluate the sales potential of products and services developed by the young ventures in which the angel group members are offered to invest, either directly or through sidecar funds. Financial experience is associated with the participation in fund investment committees, which might be explained by finance executives having a greater awareness and expertise of key issues in fund management, such as risk reduction through diversification and the assessment of potential financial returns. The association between legal experience and deal sourcing activities might be due to the fact that legal advisors are, due to their networks, particularly well placed to identify companies which consider or prepare a financing round which may involve BAs as investors.

An entrepreneurial background is not significantly associated with a stronger involvement in the studied angel group activities, which might seem surprising. Many business angels are typically entrepreneurs or former entrepreneurs (Morrissette, 2007) and, thanks to their first-hand experience in building and growing a venture, they would be expected to bring value in the post-investment phase (Wiltbank, 2005) by being involved in the supervision of portfolio companies. It is to be noted however that Wiltbank (2005) failed to find an empirical relationship between the length of BAs' entrepreneurial experience and the rate of return of their investments. Further investigation needs to be made to confirm and explain our results. This is also the case of the lack of association between an experience in strategy and the involvement in the studied angel group activities.

\section{Discussion and conclusion}

Recent research on BAs has highlighted the emergence and progressive professionalization of angel networks and groups (Mason, Botelho and Harrison, 2016). Those groups collectively deliver value added service activities. The sound functioning of such groups, because they lack the resources to hire professional staff, critically depends on the active involvement of certain of its members acting as volunteers. Our study gives us deeper insight into the cognitive drivers of individual BAs' involvement and investment of human capital in diverse group activities. This first study of its kind is but one modest step towards a better understanding of the inner workings of angel groups. 
Our main contribution is to show that BAs' decision making style and professional experience are significant drivers of their involvement in BA group activities. One limitation of this research lies in the small sample size, which constrained the data analysis methods we used, and in the fact that we studied a single business angel group. Future research may address these limitations. On a more conceptual level, it should also consider the fact that what a group can achieve collectively potentially surpasses the sum of individual BAs' contributions. In fact, the actively involved volunteers can be considered as the group's more or less informal "animation team", which represents a sort of entrepreneurial team for the young angel group. Effective delivery of collective angel group services then not only depends on team members' individual characteristics but also on the animation teams' collective (or shared) cognition, which may bear some resemblance with entrepreneurial teams, as they have been studied in the wider entrepreneurship literature (Mol, Khapova and Elfring, 2015 ${ }^{1}$ ). The latter reveals that collective cognition takes individual cognitive characteristics as an input, while it is complex and dynamic in nature. Much research needs to be done to reach a thorough understanding of entrepreneurial-team cognition and, by extension, angel-groupanimation-team cognition, and its interaction with team activities. Meanwhile, major concepts derived from the wider research on team cognition, combined with first results on individual cognitive inputs by AGMs as derived from the present study, and adapted to the specific organizational form of angel groups may be instrumental in framing future research.

In figure 2, we propose a tentative model of angel group involvement which simultaneously draws on research on individual BA characteristics, as achieved in the present article, and contemporary developments on entrepreneurial team cognition as an "emergent state" (Mol, Khapova and Elfring, 2015), to achieve a coherent framework for future research on angel-group cognition. In fact, many business angels are successful former entrepreneurs or CEOs and their cognitive characteristics and decision making style have been shown to bear significant resemblance with the entrepreneurs in whose ventures they invest (Wiltbank, Read, Dew and Sarasvathy, 2009). Most former studies on angel cognition are however focused on individual angels and do not yield much guidance in understanding how these individual angels' cognitive frames (formed through training and former experience) and decision-making styles are integrated and interact in groups to bring about collective results, thus delivering group services to its various members and investee firms. To make progress on that front, we need to make additional effort in establishing more integrative frameworks in the future. In the absence of preexisting specific contributions of that sort in angel group research, we may draw inspiration from the recent literature on entrepreneurial team cognition (Mol, Khapova and Elfring, 2015). Starting from an analogous observation to ours, namely that entrepreneurial cognition research has followed various individual avenues and is highly fragmented; they propose an integrative framework of entrepreneurial team cognition. Herein, team cognition defined as an "emergent state" is fuelled by team-members' knowledge and experience (entrepreneurial, team related, functional). Team cognition then influences organizational outputs such as opportunity recognition, learning, strategy formulation etc.

If we consider what we name an angel group's "animation team" as a specific form of entrepreneurial team, we may adapt the overall framework proposed by Mol,

\footnotetext{
${ }^{1} \mathrm{We}$ are indebted to one anonymous referee for drawing our attention to this point.
} 
Khapova and Elfring, (2015) to the specific case of angel group animation teams (that is to say all actively involved members).

Figure 2 - A model of angel group cognition and outcomes (adapted from Mol, Khapova and Elfring, 2015).

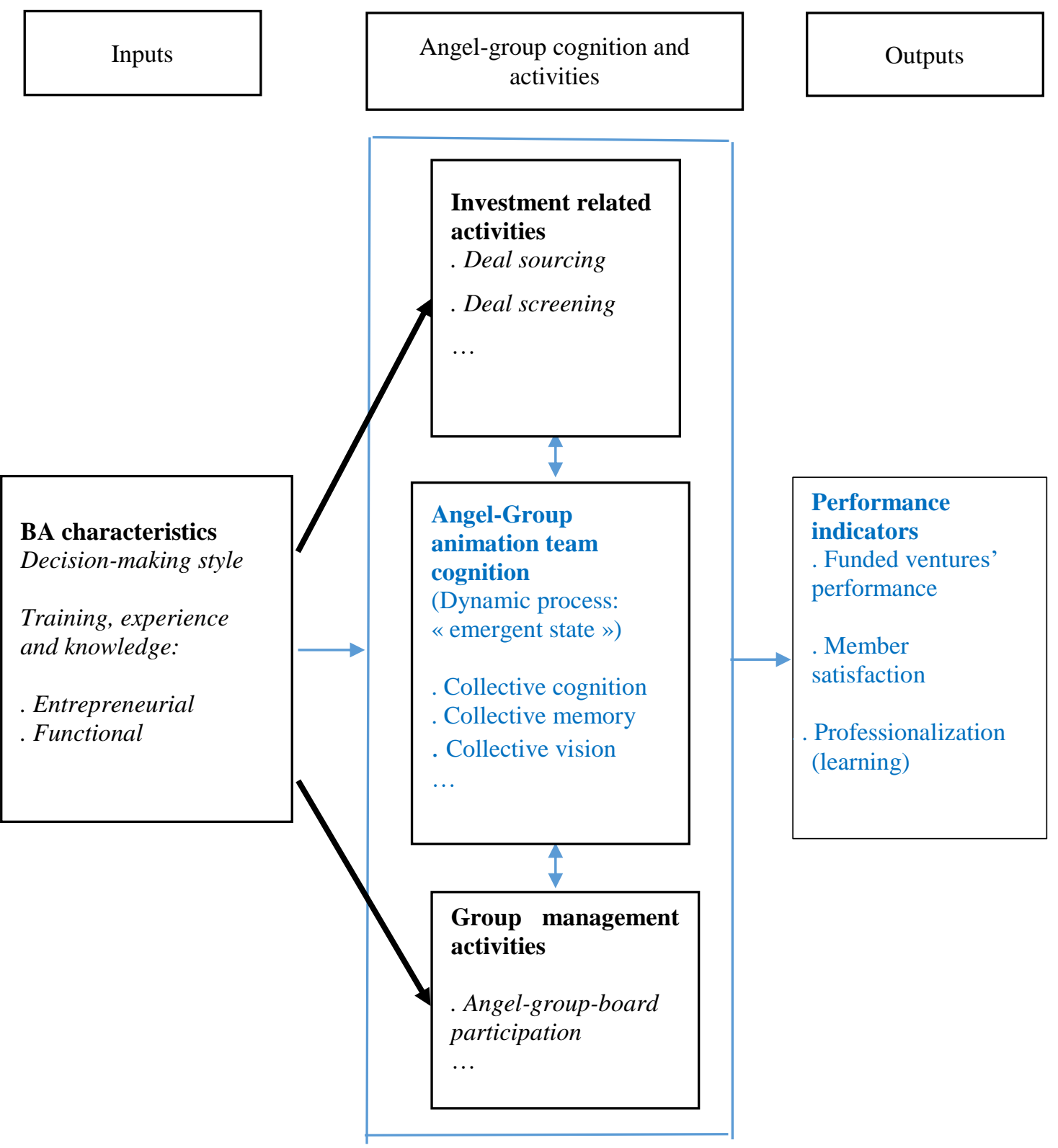

We propose this tentative model as a first step to extend research on angel group cognition in the future, and testing its relevance will require much additional research. The results of the present study underscore the relevance of a subset of relations sketched out in the framework, namely the importance of specific individual cognitive inputs (decision making style, human capital) for certain group activities, as exemplified by the two bold arrows, linking three of the five conceptual boxes. Future research would need 
to go further to explore the complex and dynamic relations tentatively represented by the light blue arrows between all five conceptual blocks. To do so would require the comparison of multiple angel groups and, potentially, recourse to complementary research methods. Because dynamic organizational processes are at stake, in-depth case studies of a few well selected angel groups may be especially valuable, albeit only one fruitful research avenue, as a helpful complement to refining quantitative measurement tools as used in the present study.

\section{References}

AERNOUDT R. (2005), «Executive forum: seven ways to stimulate business angels' investments », Venture Capital, vol. 7, n 4, p.359-371.

BONINI S., CAPIZZI V., VALLETTA M., ZOCCHI P. (2018), Angel network affiliation and business angels' investment practices, Journal of Corporate Finance, on line 17 January 2018, (https://doi.org/10.1016/j.jcorpfin.2017.12.029).

BONNET C., WIRTZ P. (2012), «Raising Capital for Rapid Growth in Young Technology Ventures: when Business Angels and Venture Capitalists Coinvest », Venture Capital, vol. 14, $\mathrm{n}^{\circ}$ 2-3, p.91-110.

BONNET C., HAON C., WIRTZ P. (2013), « Liftoff: when Strong Growth Is Predicted by Angels and Fuelled by Professional Venture Funds », Revue de l'Entrepreneuriat, vol. 12, n 4, p.59-78.

BONNET C., SÉVILLE M., WIRTZ P. (2017), « Genèse et fonctionnement du conseil d'administration d'une firme entrepreneuriale : le rôle des identifications sociales des administrateurs », Finance Contrôle Stratégie, vol. 20, n³ p.1-47.

CAPIZZI V. (2015), « The returns of business angel investments and their major determinants », Venture Capital, vol. 17, n4, p.271-298.

CARPENTIER C., SURET J.-M. (2015), « Angel Group Members’ Decision Process and Rejection Criteria: A Longitudinal Analysis », Journal of Business Venturing, vol. 30, p.808-821.

CHANDLER G., DETIENNE D., MCKELVIE A., MUMFORD T. (2011), « Causation and effectuation processes: A validation study », Journal of Business Venturing, vol. 26, p.375-390.

COLLEWAERDT V., MANIGART S., ARNOUDT R. (2010), «Assessment of Government Funding of Business Angel Networks in Flanders », Regional Studies, vol. $44, \mathrm{n}^{\circ} 1, \mathrm{p} .119-130$.

CROCE A., GUERINI M., UGHETTO E. (2018), « Angel Financing and the Performance of High-Tech Start-Ups », Journal of Small Business Management, vol. 56 $\mathrm{n}^{\circ} 2$, p.208-228.

EBAN. (2014), Directory of Business Angel Networks, (www.eban.org).

HARRISON R., MASON C., ROBSON P. (2010), " Determinants of longdistance investing by business angels in the UK », Entrepreneurship \& Regional Development, vol. 22, n², p.113-137.

KERR W.R., LERNER J., SCHOAR A. (2014), " The consequences of entrepreneurial finance: Evidence from angel financings », Review of Financial Studies, vol. $27, \mathrm{n}^{\circ} 1, \mathrm{p} .20-55$.

MADILL J., HAINES G., RIDING A. (2005), « The Role of Angels in Technology SMEs: A Link to Venture Capital », Venture Capital, vol. 7, n² 2, p.107-129. 
MASON C., BOTELHO T., HARRISON R. (2016), « The transformation of the business angel market: empirical evidence and research implications », Venture Capital, vol. $18, \mathrm{n}^{\circ} 4, \mathrm{p} .321-344$.

MASON C., HARRISON R. (2002), «Barriers to investment in the informal venture capital Sector », Entrepreneurship and Regional Development, vol. 14, p.271287.

MOL E., KHAPOVA N., ELFRING T. (2015), « Entrepreneurial Team Cognition: A Review », International Journal of Management Reviews, vol. 17, p.232255.

MORRISSETTE S. (2007), «A Profile of Angel Investors », The Journal of Private Equity, p.52-66. OECD.

OECD. (2011), Financing High Growth Firms: The Role of Angel Investors. Paris:

PAUL S., WHITTAM G. (2010), «Business angels syndicates: an exploratory study of gatekeepers », Venture Capital, vol. 12, n 3, p.241-256.

RIDING A. (2008), « Business angels and love money investors: segments of the informal market for risk capital », Venture Capital, vol. 10, n 4 , p.355-369.

SAN JOSE A., ROURE J., AERNOUDT R. (2005), « Business angels academies: unleashing the potential for business angel investment », Venture Capital, vol. 7, ${ }^{\circ} 2$, p.149-165.

SHANE S.A. (2005), Angel investing: A report prepared for the Federal Reserve banks of Atlanta, Cleveland, Kansas City, Philadelphia and Richmond (http://ssrn.com/abstract1/41142687).

SOHL J. (2007), The Organization of the Informal Venture Capital Market, In Handbook of Research on Venture Capital, edited by H. Landström, Cheltenham: Edward Elgar.

WALLMEROTH J., GROH A.P., WIRTZ P. (2018), « Venture Capital, Angel Financing, and Crowdfunding of Entrepreneurial Ventures: A Literature Review », Foundations and Trends in Entrepreneurship, vol. 14, n ${ }^{\circ}$, p.1-129.

WETZEL W. E. (1983), « Angels and informal risk capital », Sloan Management Review, vol. 24, n 4 , p.23-34.

WILTBANK R. (2005), «Investment practices and outcomes of informal venture investors », Venture Capital, vol.7, n 4 , p.343-357.

WILTBANK R., READ S., DEW N., SARASVATHY S. (2009), «Prediction and control under uncertainty: Outcomes in angel investing », Journal of Business Venturing, vol. 24, p.116-33.

ZU KNYPHAUSEN-AUFSESS D., WESTPHAL R. (2008), « Do Business Angel Networks Deliver Value to Business Angels? », Venture Capital, vol. 10, $\mathrm{n}^{\circ} 2$, p.149-169. 